\title{
Air Quality and its Effect on Health: A Geographical Perspective of Lucknow City
}

Dr. Dipak Prasad ${ }^{\dagger}$ and Dr. (Mrs.) Srabani Sanyal ${ }^{\top}$

\section{Abstract}

Erudite groups of people, scientists, planners, and policy-makers of different countries have come to realise that quality of environment is not necessarily a simple function of nature as in primitive earth. Today nature's self-regulatory functions are inoperative. All the developed and developing countries are deeply concerned to make balance between their environmental anxiety and their economic development. Dreadful environmental conditions are affecting the biological segment of the ecosystem of these areas. Human being, 'one of the most precious component in biosphere', have regular predicament situation with accretion of sullied air, water, and soil degradation. Though water and land pollution is extremely dangerous, air pollution has its own peculiarities, due to its trans-boundary dispersion of pollutants over the entire world. The effect of air pollution on health is very complex as there are many different sources and their individual effect varying from one to other. It is not only the ambient air quality in the cities but also the indoor air quality in the rural and urban areas that are causing concern.

The study is confined with the health impact of deteriorating air quality in Lucknow city. The aim of the present study is also to determine the consequences of ambient air quality on health of the people in the study area.

Key words: Air Quality, Air Pollutants, Air-borne Disease, Effect on Health, Lucknow, India

\footnotetext{
+ Post Doctorate Fellow, Department of Geography, Banaras Hindu University, Varanasi, 221005, Email: dprasadbhu@gmail.com

${ }^{\top}$ Assistant Professor, Department of Geography, Banaras Hindu University, Varanasi, 221005, Email: srabani72@gmail.com

(C) 2016 Prasad and Sanyal. This is an Open Access article distributed under the terms of the Creative Commons Attribution License (http://creativecommons.org/licenses/by/2.0), which permits unrestricted use, distribution, and reproduction in any medium, provided the original work is properly cited.
} 


\section{Introduction}

The key objective of this research is to identify air pollutants and its concentration in Lucknow, the capital city of Uttar Pradesh, India. In doing so, it tries to evaluate the impact of air pollutants on human health as concentration show increasing trend in the city.

It remains well documented that rapid industrialisation, unplanned urbanisation, population and vehicular growth has brought environmental problem in both developing and developed countries. Air pollution is release or occurrence of any foreign material or gas into the atmosphere, which may be harmful to man, animals and vegetation, etc. (Narayan, 2009). In 1996, World Health Organization defined air pollution as "substances put into the air by activity of mankind into concentrations sufficient to cause harmful effects to health, property, crop yield, or to interfere with the enjoyment of property". In general terms, air pollution may be defined as the disequilibrium condition of the air caused due to introduction of foreign elements from natural as well as anthropogenic sources to the air so that the air becomes injurious to biological communities in general and human community in particular. Major cities throughout the world have become over burdened with gases emitted by automobiles. The annual concentration of PM10 is maximum in Peshawar $\left(540 \mathrm{ug} / \mathrm{m}^{3}\right)$ followed by Rawalpindi $\left(448 \mathrm{ug} / \mathrm{m}^{3}\right)$, Mazar-eSharif $\left(334 \mathrm{ug} / \mathrm{m}^{3}\right)$, Gwalior $\left(329 \mathrm{ug} / \mathrm{m}^{3}\right)$, Ahvaz $\left(320 \mathrm{ug} / \mathrm{m}^{3}\right)$, Hamad Town $\left(318 \mathrm{ug} / \mathrm{m}^{3}\right)$, Raipur $\left(305 \mathrm{ug} / \mathrm{m}^{3}\right)$, Delhi $\left(286 \mathrm{ug} / \mathrm{m}^{3}\right.$, Karachi $(273$ $\left.\mathrm{ug} / \mathrm{m}^{3}\right)$, Lucknow $\left(219 \mathrm{ug} / \mathrm{m}^{3}\right)$, Delhi (153 $\left.\mathrm{ug} / \mathrm{m}^{3}\right)$, Patna $\left(149 \mathrm{ug} / \mathrm{m}^{3}\right)$, Gwalior $\left(144 \mathrm{ug} / \mathrm{m}^{3}\right)$ and Raipur (134 ug/m $\left./ \mathrm{m}^{3}\right)$ (WHO, 2014a). Globally, $12 \%$ of the population are exposed to annual mean levels of PM10 or PM2.5 complying with Air Quality Guideline (AQG) levels. Annual PM10 levels increase by $6 \%$ during 2009 to 2012 in world cities (WHO, 2014b). More than 5.5 million people worldwide die prematurely every year due to household and outdoor air pollution and India and China together account for $55 \%$ of these deaths, which was 1.6 million and 1.4 million respectively in 2013 (Indo-Asian News Service, 2016). The death rate from automobile pollution is increasing rapidly in metropolitan areas. The world leaders at Conference of the Parties 21 (COP 21) held in Paris in 2015 recognised air pollution as a global problem and needs reduction in level (Ilyas, 2010). Indian cities like Mumbai, Kolkata, Delhi, Chennai and Bangalore have evidenced vehicles spewing daily more than 1000,000 kilograms of smoke into the air (Kumar, 2007). The status of ambient air in 35 metro-cities of India shows steady increase in emission of particulate matter (PM), sulphur-dioxide and nitrogendioxide from transport, industry and energy sectors. The particulate matters are five times more than the safety limits, nearly $52 \%$ of the cities are at critical $\mathrm{PM}_{10}$ level (equal or more than 1.5 times limit) (CPCB,2010).

Against these backdrops and as stated above, this research aims to identify air pollutants and its concentration in Lucknow city. Alongside, it also tries to evaluate the impact of air pollutants on human health as concentration show increasing trend in the city is $204 \mu \mathrm{g} / \mathrm{m}^{3}$, whereas, RSPM level is $156 \mu \mathrm{g} / \mathrm{m}^{3}$ in Agra followed by Faridabad $\left(164 \mathrm{\mu g} / \mathrm{m}^{3}\right)$, Patna (165 $\left.\mu \mathrm{g} / \mathrm{m}^{3}\right)$, Meerut $\left(170 \mu \mathrm{g} / \mathrm{m}^{3}\right)$ etc. The $\mathrm{NO}_{\mathrm{x}}$ level in Lucknow city is also high with $34 \mu \mathrm{g} / \mathrm{m}^{3}$ in comparison to other metro-cities like Agra (11 $\left.\mu \mathrm{g} / \mathrm{m}^{3}\right)$, Varanasi $\left(20 \mathrm{\mu g} / \mathrm{m}^{3}\right)$, Mumbai (21 $\left.\mu \mathrm{g} / \mathrm{m}^{3}\right)$, Allahabad $\left(24 \mu \mathrm{g} / \mathrm{m}^{3}\right)$, Faridabad (30 $\left.\mu \mathrm{g} / \mathrm{m}^{3}\right)$, Ludhiana $\left(32 \mu \mathrm{g} / \mathrm{m}^{3}\right.$ ) etc. (CPCB, 2010). This shows that air quality status in Lucknow city particularly in central and southern part is highly polluted (Verma, 2004).

The effect of air pollution on health is very complex as there are different sources and their individual effects vary from one to another. The World Health Organization declared air pollution as human carcinogen like tobacco smoke, asbestos and arsenic, calling it a leading cause of cancer deaths globally (Los Angeles Times, 201 ${ }^{3}$ ). More than 1,000 million city dwellers of the world are exposed to high level of air pollutants, associated with respiratory disease, cause of high mortality rate (Pandey, 1997). About $60 \%$ of air pollution in all major 
cities is caused by automobiles only. The effect of these pollutants is observed at acute level on sensitive species, both plants and animals. Acute and chronic symptoms are observed to support the investigation regarding accumulation of pollutants (Horaginamani, 2010). Prevalence of bronchitis, cough, sore throat, eye irritation and general ill health in United States are due to increase in level of air pollution (Becker, 1968). Studies reveal that air pollution is positively associated with death from lung cancer and cardiopulmonary disease (Dockery, 1993). About 29,000 people die annually from exposure to particulate matter. That number rises to 40,000 when other pollutants, such as nitrogen dioxide, are considered. WHO estimates that 3.7 million people die annually from ambient air pollution, again most of whom (2.6 million) live in Asia (Royal College of Physicians, 2016).

The critical view of the report by Royal College of Physicians, "Every breath we take: the lifelong impact of air pollution" by Lancet editorial writes that this is an important statement of evidence and intent. But this effort might not be enough to make much difference. Therefore, it is an ardent need to research on magnitudes of air pollution in different parts of the world (here, the case of Lucknow city) (The Lancet Editorial, 2016).

India faces an unprecedented public health crisis arising from air pollution as reported by Centre for Science and Environment's (CSE) and Global Burden of Disease. About $6,20,000$ premature deaths have occurred from airborne diseases due to burning of fuel wood and biomass, fuel adulteration, vehicle emission and traffic congestion. Air pollution is the fifth leading cause of death in India after high blood pressure, indoor air pollution, tobacco smoking and poor nutrition (The Times of India, 2013b). After WHO classified pollution as carcinogenic to humans, it was reported that around $20 \%$ of lung cancer patients in Hyderabad city have eventually died due to exposure to high level of air pollution (IEA, 2012). Central Pollution Control Board reported an increase in carcinogenic agents like benzene and ozone during summers in cities because of turbulence which mixes and enhances the dispersion of pollutants (The Times of India, 2013a). In Chennai, alarmingly prevalence of respiratory problems is due to automobile emissions. Episodes of difficulty in breathing are triggered by allergens, infections and environmental pollutants. Large chunk of patients with asthma and bronchitis also suffer from dust allergy (Sampath, 20133). More than 10,000 premature deaths have occurred in Kolkata due to increase in SPM level. SPM concentration of ambient air varies from $227.1 \mu \mathrm{g} / \mathrm{m}^{3}$ to 397 $\mu \mathrm{g} / \mathrm{m}^{3}$ with mean concentration of $310 \mu \mathrm{g} / \mathrm{m}^{3}$ (Ghose, 2005). According to Ministry of Health and Family Welfare (2009), 1,500,000 patients are registered for TB treatment in India, of which 2, 77,000 are alone from Uttar Pradesh, while it was 6,734 in Lucknow city. Number of TB patients continuously increases (172\%) from 2265 (2001) to 6177 (2011) with decadal growth of $172 \%$ (Central Bureau of Health Intelligence, 2012). Therefore, it is important to investigate the status of air quality and its impact on health in Lucknow city. The present research work is structured to evaluate the state of environment in Lucknow city, assess the concentration of pollutants in different parts of city during pre and post monsoon period because pollutants in ambient air are controlled by climatic elements such as speed and direction of wind, relative humidity, and temperature (Jayamurugan, 2013). The study also determines the effect of poor air quality through a perspective study to specify appropriate mitigative measures for Lucknow city.

The research begins with a description of the study area followed by a discussion of the methodological issues involved. Following this, it discusses the air quality of the city in the pre monsoon and post monsoon period. Finally, it discusses the impact of air pollution on health consequences.

\section{Study Area}

Lucknow, the 'City of Gardens', is located in Middle Gangetic Plain, from 2630' to 2710' latitude and 8013' to 8030' longitudes (Fig.1). 
It enjoys subtropical climate with cool dry winter (December - February) and summer (March - June). The average temperature is about $45^{\circ} \mathrm{C}$ in summer and $30^{\circ} \mathrm{C}$ in winter, with annual rainfall of about $100 \mathrm{~cm}$ (Meteorological Centre, 2010).

The total population of Lucknow city is $2,815,601$ persons and the geographical area is reported to be 310.10 sq. Km (Census of India, 2011). Lucknow Municipal Corporation (LMC) has been divided into 110 wards and 6 zones for administrative purposes. The city witnessed about 162\% increase in urban area from 1981 to 2011. The ever increasing population and rapid pace of urbanisation have created a number of problems such as shortage of dwelling units, mushrooming growth of slums, encroachment of public land and expansion of unauthorised colonies (Government of India, 2002).

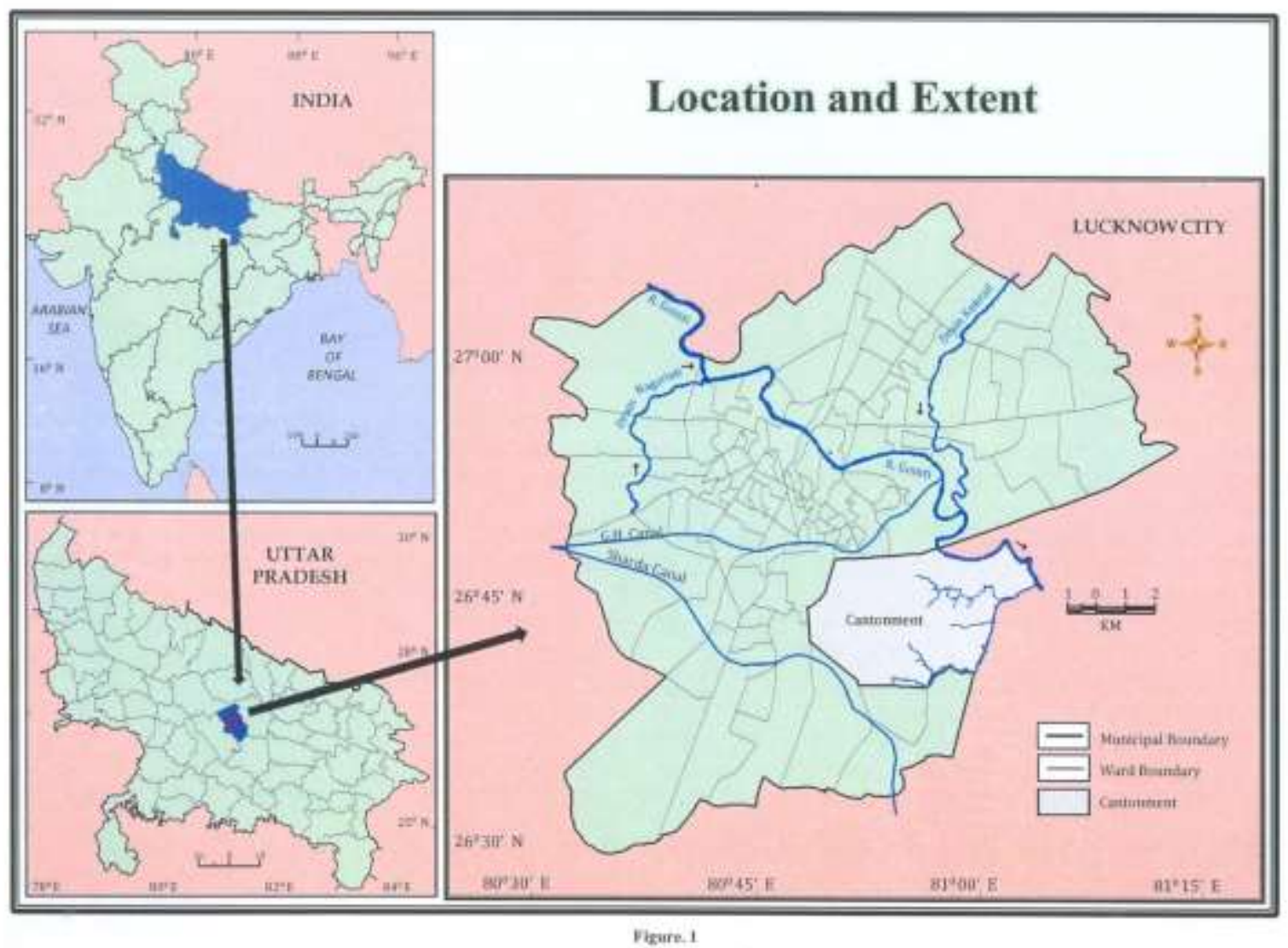

\section{Methodology}

The monitoring stations are selected on the basis of their locations and on earlier studies (Berman, 2010; Shukla, 2010 etc.). Further, to assess the ambient air quality status in Lucknow city during pre and post period, air pollutants namely Respirable Particulate Matter (RSPM or PM10), Suspended Particulate Matter (PM2.5), Sulphur dioxide $\left(\mathrm{SO}_{2}\right)$, Oxides of Nitrogen Oxide $\left(\mathrm{NO}_{\mathrm{x}}\right)$ and Carbon monoxide (CO) are monitored and categorised from residential, commercial and industrial areas. For this purpose, 14 sample stations namely- Vikas Nagar, Indira Nagar, Aliganj, Mahanagar, Gomti
Nagar (residential area); Chowk, Hazaratganj, Sarai Mali K., Aminabad, Hussainganj, Charbagh, Alambagh (commercial area); Talkatora and Amausi (industrial area) are selected. The concentration of pollutants is low during rainy season (July to October) due to speed of wind and process of dispersion. During rainy season, Lucknow city receives $200 \mathrm{~mm}$ of rainfall, as a result the concentration of air pollutants are lowest during this period. During November to February (post-monsoon period) the concentration of gaseous pollutants like $\mathrm{SO}_{2}$ and $\mathrm{NO}_{\mathrm{x}}$ remain very high due to calm weather condition and less dispersion, whereas, in the month of March and upto monsoon arrival, 
concentration of particulates and gaseous pollutants higher because of turbulence which mixes and enhances the dispersion of pollutants (Narayan, 2009). Therefore, present study considers pre- and post-monsoonal change in concentration of pollutants.

To study prevailing environmental problems and health consequences related to deteriorating air quality in Lucknow city, 800 respondents belonging to different crosssections of the community were intensively interviewed and information thus obtained were tabulated and scientifically analysed using correlation and regression to find out the relationship between air pollutants and diseases occurring.

\section{Air Quality in Lucknow city}

\section{Pre-Monsoon}

Table 1 depicts concentration of air pollutants during pre and post-monsoon period in Lucknow City from 2008-2011. Maximum 24 hours mean concentration of RSPM was observed in Indira Nagar $\left(200.8 \mu \mathrm{g} / \mathrm{m}^{3}\right)$ which is a residential area followed by Alambagh $\left(227.28 \mathrm{\mu g} / \mathrm{m}^{3}\right)$, a commercial area. It was observed that PM10 values are above the permissible limit $\left(100 \mathrm{\mu g} / \mathrm{m}^{3}\right.$ for industrial, residential, rural and other area respectively) as prescribed by National Ambient Air Quality Standard (NAAQS). This may be due to huge traffic load, congestion at major bus and railway stations, at commercial centres etc. causing high concentration of air pollutants both during day time and night time. It was also found that Indiranagar has high concentration of air pollutants because of spurt in construction activities, decline in number of trees and increased vehicular traffic density.

Concentration of fine particulate matters was observed maximum in Indira Nagar (339.65 $\mu \mathrm{g} / \mathrm{m}^{3}$ ) which is a newly developed residential cum commercial area. As a result, high concentration of SPM level has been observed due to mix functional characteristics. SPM concentration is high $\left(410.0 \mathrm{\mu g} / \mathrm{m}^{3}\right)$ also in Charbagh probably because of being a commercial centre and also due to heavy influx of automobiles and people during working hours (Table 1).

In Lucknow city, mean level of $\mathrm{SO}_{2}$ ranges between $7.42 \mu \mathrm{g} / \mathrm{m}^{3}$ to $21.13 \mu \mathrm{g} / \mathrm{m}^{3}$ with an average of $14.79 \mu \mathrm{g} / \mathrm{m}^{3}$. All the values of $\mathrm{SO}_{2}$ are well below the prescribed NAAQS level ( 80 $\mu \mathrm{g} / \mathrm{m}^{3}$ ) for all the sample stations (Table 2.9). Study also reveals that concentration of $\mathrm{CO}$ and NOx are well within the permissible limit $(4000$ $\mu \mathrm{g} / \mathrm{m}^{3}$ and $80 \mu \mathrm{g} / \mathrm{m}^{3}$ respectively) as given by Central Pollution Control Board (CPCB) at all the sample stations. $\mathrm{CO}$ and $\mathrm{NO}_{x}$ ranges between $349.50 \mu \mathrm{g} / \mathrm{m}^{3}$ to $1130.00 \mu \mathrm{g} / \mathrm{m}^{3}$ and 26.38 $\mathrm{\mu g} / \mathrm{m}^{3}$ to $35.05 \mu \mathrm{g} / \mathrm{m}^{3}$ respectively (Table 1 )

Thus, it is quite vibrant from the above discussion that concentration of pollutants shows wide variation within the city. It has emerged from the study that concentration of pollutants are high in the central part of Lucknow city when compared to the south and north-east (except Indira Nagar) due to high population and vehicular concentration, varied commercial and industrial activities (small scale).

\section{Post-Monsoon}

During Post-monsoon period mean concentration of RSPM was high in Mahanagar $\left(170.02 \mu \mathrm{g} / \mathrm{m}^{3}\right)$ located in residential area and Alambagh $\left(194.58 \mu \mathrm{g} / \mathrm{m}^{3}\right)$ in commercial area. All the values of PM10 are well above the prescribed National Ambient Air Quality Standard (NAAQS) of $100 \mu \mathrm{g} / \mathrm{m}^{3}$ for industrial, residential and commercial areas (Table 2 ).

Fine particles was observed maximum in Mahanagar $\left(362.72 \mathrm{\mu g} / \mathrm{m}^{3}\right)$ (Residential area) and Alambagh $\left(398.85 \mu \mathrm{g} / \mathrm{m}^{3}\right)$ commercial area. The concentration of SPM in commercial areas was high due to heavy influx of automobiles and population during peak hour. Newly emerged residential cum commercial area like Indira Nagar have high concentration of SPM level due to its functional characteristics like manufacturing, building and road construction, transportation and communication, etc. (Table. 1). 
Table 1 : Concentration of Air Pollutant, Pre and Post-monsoon, Lucknow City, 2008-2011

Average Concentration $\left(\mu \mathrm{g} / \mathrm{m}^{3}\right)$

\begin{tabular}{|c|c|c|c|c|c|c|c|c|c|c|c|}
\hline \multirow{2}{*}{ 选 } & \multirow{2}{*}{$\begin{array}{l}\text { Sample } \\
\text { Station }\end{array}$} & \multicolumn{2}{|l|}{ SPM } & \multicolumn{2}{|l|}{ RSPM } & \multicolumn{2}{|l|}{$\mathrm{SO}_{2}$} & \multicolumn{2}{|l|}{$\mathrm{CO}$} & \multicolumn{2}{|l|}{$\mathrm{NO}_{\mathrm{x}}$} \\
\hline & & $\begin{array}{l}\text { Pre- } \\
\text { mon. }\end{array}$ & $\begin{array}{l}\text { Post- } \\
\text { mon. }\end{array}$ & $\begin{array}{l}\text { Pre- } \\
\text { mon. }\end{array}$ & $\begin{array}{l}\text { Post- } \\
\text { mon. }\end{array}$ & $\begin{array}{l}\text { Pre- } \\
\text { mon. }\end{array}$ & $\begin{array}{c}\text { Post- } \\
\text { mon } \\
.\end{array}$ & $\begin{array}{l}\text { Pre- } \\
\text { mon. }\end{array}$ & $\begin{array}{l}\text { Post- } \\
\text { mon. }\end{array}$ & $\begin{array}{l}\text { Pre- } \\
\text { mon. }\end{array}$ & $\begin{array}{c}\text { Post- } \\
\text { mon } \\
.\end{array}$ \\
\hline \multirow{6}{*}{ 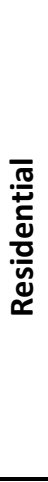 } & Vikas Nagar & 339.7 & $\begin{array}{l}311 . \\
6\end{array}$ & 168.1 & $\begin{array}{l}152 . \\
5\end{array}$ & 17.7 & 19.0 & 349.5 & 520.0 & 29.5 & 29.6 \\
\hline & $\begin{array}{l}\text { Indira } \\
\text { Nagar }\end{array}$ & 379.5 & $\begin{array}{l}353 . \\
2 \\
\end{array}$ & 200.1 & $\begin{array}{l}163 . \\
8 \\
\end{array}$ & 17.8 & 22.6 & 978.6 & 630.0 & 29.1 & 34.5 \\
\hline & Aliganj & 356.9 & $\begin{array}{l}298 . \\
8\end{array}$ & 145.7 & $\begin{array}{l}141 . \\
9\end{array}$ & 14.6 & 18.0 & 477.6 & 480.0 & 26.9 & 30.1 \\
\hline & Mahanagar & 362.7 & $\begin{array}{l}362 . \\
7 \\
\end{array}$ & 170.0 & $\begin{array}{l}170 . \\
0 \\
\end{array}$ & 7.4 & 7.4 & 601.9 & 543.3 & 33.9 & 33.9 \\
\hline & $\begin{array}{l}\text { Gomti } \\
\text { Nagar }\end{array}$ & 347.0 & $\begin{array}{l}334 . \\
3\end{array}$ & 175.8 & $\begin{array}{l}148 . \\
2\end{array}$ & 15.0 & 21.2 & 466.0 & 640.0 & 26.4 & 30.2 \\
\hline & Standard & 100 & & 60 & & 80 & & 4000 & & 80 & \\
\hline \multirow{8}{*}{ 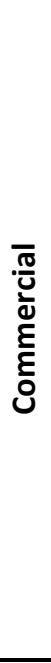 } & Chowk & 353.9 & $\begin{array}{l}382 . \\
4\end{array}$ & 198.0 & $\begin{array}{l}184 . \\
5\end{array}$ & 17.2 & 23.8 & 1025.2 & $\begin{array}{l}1000 . \\
0\end{array}$ & 31.5 & 40.2 \\
\hline & Hazaratganj & 358.1 & $\begin{array}{l}358 . \\
1 \\
\end{array}$ & 174.6 & $\begin{array}{l}174 . \\
6 \\
\end{array}$ & 7.7 & 7.7 & 1016.5 & $\begin{array}{l}1162 . \\
5\end{array}$ & 33.7 & 33.7 \\
\hline & $\begin{array}{l}\text { Sarai Mali } \\
\text { K. }\end{array}$ & 368.5 & $\begin{array}{l}368 . \\
5 \\
\end{array}$ & 173.1 & $\begin{array}{l}173 . \\
1 \\
\end{array}$ & 8.0 & 8.0 & 1068.9 & $\begin{array}{l}1066 . \\
7\end{array}$ & 34.7 & 34.7 \\
\hline & Aminabad & 371.6 & $\begin{array}{l}347 . \\
9\end{array}$ & 189.2 & $\begin{array}{l}169 . \\
3\end{array}$ & 17.6 & 22.4 & 862.1 & $\begin{array}{l}1450 . \\
0\end{array}$ & 28.4 & 36.3 \\
\hline & $\begin{array}{l}\text { Hussaingan } \\
\text { j }\end{array}$ & 422.4 & $\begin{array}{l}336 . \\
5\end{array}$ & 205.0 & $\begin{array}{l}165 . \\
5\end{array}$ & 21.1 & 21.4 & 1130.0 & 980.0 & 35.8 & 37.3 \\
\hline & Charbagh & 410.5 & $\begin{array}{l}387 . \\
3\end{array}$ & 202.2 & $\begin{array}{l}185 . \\
6\end{array}$ & 20.2 & 24.6 & 1001.9 & $\begin{array}{l}1210 . \\
0\end{array}$ & 34.8 & 43.6 \\
\hline & Alambagh & 374.7 & $\begin{array}{l}398 . \\
9\end{array}$ & 227.3 & $\begin{array}{l}194 . \\
6\end{array}$ & 19.7 & 25.2 & 1071.8 & $\begin{array}{l}1010 . \\
0\end{array}$ & 33.9 & 41.5 \\
\hline & Standard & 100 & & 60 & & 80 & & 4000 & & 80 & \\
\hline \multirow{3}{*}{ 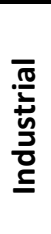 } & Talkatora & 390.0 & $\begin{array}{l}390 . \\
0 \\
\end{array}$ & 187.6 & $\begin{array}{l}187 . \\
6 \\
\end{array}$ & 8.2 & 8.2 & 962.7 & 980.4 & 36.1 & 36.1 \\
\hline & Amausi & 356.6 & $\begin{array}{l}313 . \\
0 \\
\end{array}$ & 168.4 & $\begin{array}{l}148 . \\
6 \\
\end{array}$ & 14.9 & 21.2 & 803.8 & 870.0 & 30.1 & 34.9 \\
\hline & Standard & 100 & & 60 & & 80 & & 4000 & & 80 & \\
\hline
\end{tabular}

Source: Indian Institute of Toxicology Research (IITR), Lucknow, 2008-2011.

Table 2: How do air pollutants affect you and your family during last one year?

\begin{tabular}{|c|c|c|c|c|}
\hline \multirow{2}{*}{ Age-group } & \multicolumn{4}{|c|}{ Air pollutant and their effect } \\
\hline & Health Problems & Disease & No response & Total \\
\hline Below 18 & 188 & 0 & 24 & $212(26.5)$ \\
\hline $18-30$ & 136 & 44 & 20 & $200(25.0)$ \\
\hline $31-60$ & 200 & 60 & 16 & $276(34.5)$ \\
\hline Above 60 & 108 & 4 & 0 & $112(14.0)$ \\
\hline Total & $632(79.00)$ & $108(13.5)$ & $60(7.5)$ & $800(100)$ \\
\hline
\end{tabular}

Source: Personal Survey, 2014 
The level of $\mathrm{SO}_{2}, \mathrm{CO}$ and $\mathrm{NO}_{x}$ are also below the prescribed limit as observed during premonsoon period. $\mathrm{SO}_{2}$ level was as high as 18.99 $\mathrm{\mu g} / \mathrm{m}^{3}$ in commercial area such as Alambagh, Charbagh and Chowk due to heavy traffic congestion and influx of people during peak hours, whereas, CO concentration was high in commercial areas like Aminabad and Charbagh with $1450 \mu \mathrm{g} / \mathrm{m}^{3}$ and $1210 \mathrm{\mu g} / \mathrm{m}^{3}$ respectively. $\mathrm{NO}_{x}$ ranges between $29.59 \mu \mathrm{g} / \mathrm{m}^{3}$ to 43.60 $\mu \mathrm{g} / \mathrm{m}^{3}$ in Vikas nagar and Charbagh respectively. The average concentration of $\mathrm{NO}_{x}$ level in Lucknow city during post monsoon was $35.46 \mu \mathrm{g} / \mathrm{m}^{3}$ (Table 1).

\section{Air Pollution and Health Consequences}

To know the major sources of air pollutants in Lucknow city a perception study was conducted to assess the opinion of respondents according to their educational level towards deteriorating air quality and its impact on health in Lucknow city. 800 respondents were interviewed among which $23.5 \%$ (188) are illiterates and $76.5 \%$ (612) are literates. It is interesting to note that out of the total respondents, $52 \%$ mentioned that automobile is the major source of air pollution followed by industries (30.5\%) and indoor air or domestic pollutants (1.5\%).

To assess the effect of air pollutants, respondents according to their age-group were asked a question "How did air pollution affect you and your family during the last one year?" Table 2 reveals that 79\% respondents considered air pollution as one of the major reasons for their poor health conditions, due to prevalence of respiratory problems, suffocation, eye irritation, skin problems, etc. followed by airborne diseases like asthma,

Table 3: Health problems faced by respondents during the last two years due to air pollution

Type of Health Problem

\begin{tabular}{lcccccc} 
& \multicolumn{5}{c}{ Type of Health Problem } \\
\cline { 2 - 8 } Occupation & Suffocation & Eye Irritation & Skin Problem & $\begin{array}{c}\text { Respiratory } \\
\text { Problem }\end{array}$ & No Problem & Total \\
\hline Govt. Service & 4 & 20 & 8 & 112 & 16 & $160(20.0)$ \\
\hline Business & 96 & 56 & 4 & 124 & 52 & $332(41.5)$ \\
\hline Industrial Worker & 24 & 52 & 0 & 28 & 0 & $104(13.0)$ \\
\hline Agricultural Labour & 0 & 0 & 28 & 0 & 0 & $28(3.5)$ \\
\hline Others & 40 & 28 & 0 & 92 & 16 & $176(22.0)$ \\
\hline Total & $164(20.5)$ & $156(19.5)$ & $40(5.0)$ & $356(44.5)$ & $84(10.5)$ & $800(100)$ \\
Source: Personal Survey, 2014 & & & & &
\end{tabular}

bronchitis, TB, lung cancer (13.5\%). About 7.5\% did not respond to the question. It is quite obvious that the respondents $(55.55 \%)$ in the age-group of 31-60 who have to travel by bus through crowded areas for their job are more affected by outdoor air pollution. About $31 \%$ of respondents belonging to age-group 31-60 suffer from chronic health problems (asthma, diabetes, cancer etc.) and $42.85 \%$ suffer from smoke or dust. The reason may be due to their occupation, travel duration or location of their residence.

Further, to perceive the response regarding the effect of outdoor air pollution, a question was asked to the respondents according to their occupational structure, "Mention the health problems that you faced during the last two years due to outdoor air pollution".

Table 3 reveals that $44.5 \%$ suffer from respiratory problems followed by suffocation (20.5\%), eye irritation (19.5\%) and skin problems (5\%). About $10.5 \%$ of the respondents particularly agricultural labourers and farmers mentioned that they are not affected by outdoor air pollution, maybe due to their occupation. About $58 \%$ of the respondents engaged in business reported to suffer from suffocation due to their long stay in congested commercial areas, followed by industrial workers (14.63\%) affected from industrial effluents and others (24.39\%). Similarly, respondents engaged in government service and businesses $(31.46 \%, 34.83 \%$ respectively) also suffer from respiratory problems. About 70\% agricultural labourers have skin problems due to heavy use of pesticides, urea, etc. 


\section{DOI: 10.20896/saci.v4i1.164}

\section{Incidence of Air-borne diseases}

The health effects due to deteriorating air quality came under public and scientific scrutiny as early as the 1930s, following several incidents of mortality due to air pollution. Several epidemiological studies have demonstrated a clear link between respiratory diseases and the levels of particulate in air pollution. Premature death due to SPM is reported to be very high and the worst effected groups of children are in Kolkata (Ghose, 2005). Gaseous pollutants are related with respiratory diseases and reproductive and developmental effect (Barman, 2010). Perfect solutions to the problem of airborne disease transmission do not yet exist, but the available technologiesoutside purge air, filtration etc. can be successfully implemented when their characteristic effects are understood and the goals clearly defined (Kowalski, 1998).

Therefore, it is important to analyse the perception of the respondents regarding airborne diseases and their occurrence. Table 4 shows the responses to the question, "Incidence of Air-borne diseases among respondents". It is reported that maximum number of respondents are suffering from incidences of high blood pressure (47.1\%) due to elevated levels of Carboxyl Haemoglobin in blood, followed by eye infection and irritation (30.6\%) due to exhaust emission from the automobiles etc. Respiratory problems,

\section{Table 4: Incidence of Air-borne Diseases Among}

particularly viral respiratory infections are most frequently occurring due to high concentration of airborne allergens such as aerosol, SPM, $\mathrm{RSPM}, \mathrm{NO} 2, \mathrm{SO}_{2}$ etc. In the congested and older part of the city, poor ventilation in dwellings and concentration of industrial activities near industrial units reported high occurrence of respiratory problem (Table 4).

In order to evaluate the occurrence of air-borne diseases in six different zones within Lucknow city, responses to the question, "prevalence of air-borne diseases among respondents in different zones" was evaluated. It is witnessed that due to heavy traffic congestion and commercial activities, the incidence of asthma is highest in Zone II (26.4\%) followed by Zone I (23.9\%) (Table 5). Further, the zones which are also located in the outer part of the city in Zone III, Zone IV, Zone V and Zone VI have reported less incidence of asthma, for example, 19.5\%, $17.6 \%, 5.0 \%$ and $7.5 \%$ respectively. The RSPM level ranges between 136.8 to $244.8 \mu \mathrm{g} / \mathrm{m}^{3}$ in the residential areas, whereas, in commercial areas it is 183.9 to $252.9 \mu \mathrm{g} / \mathrm{m}^{3}$. The respondents are also suffering from bronchitis, tuberculosis, eye infection and congenial heart diseases, which are possibly due to high prevalence of sulphur dioxide and nitrogen dioxide causing inflammation of the bronchi (lungs) etc. Further, concentration of gases, particulate matters, aerosol etc. endorses the rate of these diseases.

Table 4: Incidence of Air-borne Diseases Among the Respondents, Lucknow City

\begin{tabular}{lcc} 
& \multicolumn{3}{c}{ Respondents } \\
\cline { 2 - 3 } Air-borne Disease & Number & \% \\
\hline Asthma & 159 & 19.9 \\
\hline Bronchitis & 24 & 3 \\
\hline Pneumonia & 108 & 13.5 \\
\hline Tuberculosis & 139 & 17.4 \\
\hline Lung Cancer & 31 & 3.9 \\
\hline Eye Infection & 245 & 30.6 \\
\hline High BP & 377 & 47.1 \\
\hline Congestion Heart & 152 & 19
\end{tabular}


Table 5: Prevalence of Air-borne Diseases Among Respondents in Different Zones, Lucknow City

\begin{tabular}{|c|c|c|c|c|c|c|c|c|}
\hline \multirow[b]{2}{*}{ Zone } & \multicolumn{8}{|c|}{ Air-borne Diseases Among Respondents (\%) } \\
\hline & Asthma & Bronchitis & Pneumonia & Tuberculosis & $\begin{array}{l}\text { Lung } \\
\text { Cancer }\end{array}$ & $\begin{array}{c}\text { Eye } \\
\text { Infection }\end{array}$ & $\begin{array}{c}\text { Blood } \\
\text { Pressure }\end{array}$ & $\begin{array}{c}\text { Congenial } \\
\text { Heart }\end{array}$ \\
\hline I & 23.9 & 33.3 & 14.8 & 22.3 & 12.9 & 23.3 & 16.7 & 26.3 \\
\hline II & 26.4 & 33.3 & 7.4 & 15.1 & 38.7 & 20 & 18.6 & 26.3 \\
\hline III & 19.5 & 16.7 & 29.6 & 30.9 & 35.5 & 18 & 22 & 18.4 \\
\hline IV & 17.6 & 16.7 & 33.3 & 10.1 & 12.9 & 11.4 & 11.1 & 5.3 \\
\hline $\mathrm{V}$ & 5 & 0 & 3.7 & 13.7 & 0 & 12.2 & 13 & 5.3 \\
\hline $\mathrm{VI}$ & 7.5 & 0 & 11.1 & 7.9 & 0 & 15.1 & 18.6 & 18.4 \\
\hline Total & $\begin{array}{l}100.0 \\
(159)\end{array}$ & $100(24)$ & $100(108)$ & 100 (139) & $100.0(31)$ & $100.0(245)$ & $100.0(377)$ & $\begin{array}{l}100.0 \\
(152)\end{array}$ \\
\hline
\end{tabular}

Relationship between Air Pollutants and Airborne Diseases

For the assessment of air- borne diseases like Asthma, Bronchitis, TB, Lung Cancer, Eye Infection, Congenial Heart on air quality, different air pollutants like RSPM, SPM, $\mathrm{SO}_{2}, \mathrm{CO}$ and $\mathrm{NO}_{x}$ are also correlated to find out the relationship between deteriorating air quality and increasing rate of air-borne diseases. It is observed from Table 6 that there exists a positive correlation between the two.

The SPM level is significantly and positively correlated with air-borne diseases like Asthma, Bronchitis, Congenial Heart, Eye Infection and Lung Cancer etc. RSPM is also observed positive and significantly correlated with Asthma, Bronchitis, Congenial Heart, Eye Infection, Lung Cancer and TB, whereas, $\mathrm{SO}_{2}$ is moderately correlated with air-borne diseases. $\mathrm{NO}_{x}$ and $\mathrm{CO}$ are not significantly correlated with air-borne diseases.

The regression analysis postulates that dependent variable (disease) is linearly related to series of independent variables (air pollutant) implying occurrence of airborne diseases due to increase in particulate matters (SPM and RSPM) in ambient air.

\section{SPM Vs Asthma}

Table 7 represents the strength of the linear relationship between SPM and Asthma. It also gives $R^{2}$ (Coefficient of Determination), we can see that there is strong relationship between the two variables ( $67.5 \%$ of the variation in $y$ is explained by the regression line). The coefficient table contains the coefficients for the least square (fitted) line and other relative information about the coefficients. In the column $B$, the constant represents the $y$ intercept and the SPM represents our slope. The equation of the line found from the output is

$$
\mathrm{Y}(\text { Asthma })=-130.1+0.426(\mathrm{SPM})
$$

The tabulated values of ' $\mathrm{t}$ ' (2.881) at 1\%, 2\% and at $5 \%$ 'levels of significance' for 4 degree of freedom ( $n-2$, where $n$ is 6 ) 4.60, 3.75, and 2.78 respectively. It is obvious that our calculated value is significant only at $5 \%$ level of significance. Thus the existence of a causal relationship is supported by the data also.

\section{RSPM Vs Asthma}

The coefficient of determination is .733; therefore, about $73.3 \%$ of the variation in the Asthma is explained by RSPM. The regression equation appears to be very useful for making predictions since the value of $R^{2}$ is closer to 1 rather than 0 . In the column $B$, the constant represents the $y$-intercept and the SPM represents our slope. The equation of the line found from the output is

$$
Y(\text { Asthma })=-64.496+0.538 \text { (RSPM) }
$$

Analysed data shows that if the level of RSPM goes up by $1 \mu \mathrm{g} / \mathrm{m}^{3}$, then we predict that the 
cases of Asthma will increase about 0.538, whereas, if the levels of RSPM will be $0 \mu \mathrm{g} / \mathrm{m}^{3}$ 64.496. The tabulated values of ' $\mathrm{t}$ ' (3.318) at $1 \%, 2 \%$ and at $5 \%$ 'levels of significance' for 4 degree of freedom ( $n-2$, where $n$ is 6) 4.60 ,
3.75 , and 2.78 respectively. It is obvious that our calculated value is significant only at $5 \%$ level of significance. Thus, the existence of a causal relationship is supported by the data too.

Table 6: Relationship between Air Quality and Air-borne Diseases

\begin{tabular}{|c|c|c|c|c|c|c|c|c|c|c|c|c|}
\hline & & 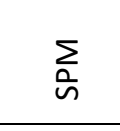 & $\sum_{\substack{0\\
}}$ & $\stackrel{n}{n}$ & ○ & $0^{x}$ & 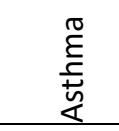 & $\begin{array}{l}\frac{c}{U} \\
\frac{\varrho}{0} \\
\frac{0}{\infty}\end{array}$ & $\stackrel{\oplus}{\vdash}$ & 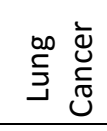 & 离 & 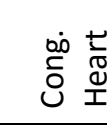 \\
\hline \multirow{2}{*}{ SPM } & $r$ & 1 & $.967 * *$ & $.902 *$ & .608 & .362 & $.821^{*}$ & $.839 *$ & .378 & .579 & .680 & .769 \\
\hline & Sig. & & .002 & .014 & .200 & .480 & .045 & .037 & .460 & .228 & .137 & .074 \\
\hline \multirow{2}{*}{ RSPM } & $r$ & $.967^{* *}$ & 1 & .795 & .562 & .441 & $.856^{*}$ & $.896 *$ & .549 & .604 & $.829 *$ & $.859 *$ \\
\hline & Sig. & .002 & & .059 & .246 & .382 & .029 & .016 & .259 & .204 & .041 & .029 \\
\hline \multirow{2}{*}{$\mathrm{SO}_{2}$} & $r$ & $.902^{*}$ & .795 & 1 & .526 & .283 & .664 & .674 & -.035 & .507 & .321 & .443 \\
\hline & Sig. & .014 & .059 & & .284 & .587 & .150 & .142 & .947 & .304 & .535 & .379 \\
\hline \multirow{2}{*}{$\mathrm{CO}$} & $r$ & .608 & .562 & .526 & 1 & .621 & .119 & .239 & .130 & -.253 & .381 & .521 \\
\hline & Sig. & .200 & .246 & .284 & & .188 & .822 & .649 & .806 & .629 & .456 & .289 \\
\hline \multirow{2}{*}{$\mathrm{NO}_{x}$} & $r$ & .362 & .441 & .283 & .621 & 1 & -.030 & .085 & .064 & -.006 & .435 & .532 \\
\hline & Sig. & .480 & .382 & .587 & .188 & & .955 & .873 & .904 & .991 & .388 & .278 \\
\hline \multirow{2}{*}{ Asthma } & $r$ & $.821^{*}$ & $.856^{*}$ & .664 & .119 & -.030 & 1 & $.975^{* *}$ & .612 & .798 & .727 & .667 \\
\hline & Sig. & .045 & .029 & .150 & .822 & .955 & & .001 & .197 & .057 & .102 & .148 \\
\hline \multirow{2}{*}{ Bronchitis } & $r$ & $.839 *$ & $.896^{*}$ & .674 & .239 & .085 & $.975 * *$ & 1 & .639 & .684 & .774 & .680 \\
\hline & Sig. & .037 & .016 & .142 & .649 & .873 & .001 & & .172 & .134 & .071 & .137 \\
\hline \multirow{2}{*}{ TB } & $r$ & .378 & .549 & -.035 & .130 & .064 & .612 & .639 & 1 & .330 & $.884^{*}$ & .742 \\
\hline & Sig. & .460 & .259 & .947 & .806 & .904 & .197 & .172 & & .523 & .019 & .091 \\
\hline \multirow{2}{*}{$\begin{array}{l}\text { Lung } \\
\text { Cancer }\end{array}$} & $r$ & .579 & .604 & .507 & -.253 & -.006 & .798 & .684 & .330 & 1 & .496 & .515 \\
\hline & Sig. & .228 & .204 & .304 & .629 & .991 & .057 & .134 & .523 & & .317 & .296 \\
\hline \multirow{2}{*}{$\begin{array}{c}\text { Eye } \\
\text { Infect. }\end{array}$} & $r$ & .680 & $.829 *$ & .321 & .381 & .435 & .727 & .774 & $.884 *$ & .496 & 1 & $.939 * *$ \\
\hline & Sig. & .137 & .041 & .535 & .456 & .388 & .102 & .071 & .019 & .317 & & .005 \\
\hline \multirow{2}{*}{$\begin{array}{l}\text { Cong. } \\
\text { Heart }\end{array}$} & $r$ & .769 & $.859 *$ & .443 & .521 & .532 & .667 & .680 & .742 & .515 & $.939 * *$ & 1 \\
\hline & Sig. & .074 & .029 & .379 & .289 & .278 & .148 & .137 & .091 & .296 & .005 & \\
\hline \multicolumn{13}{|c|}{ Source: Field Survey and Statistical Analysis, 2014} \\
\hline \multirow{2}{*}{\multicolumn{13}{|c|}{$\begin{array}{l}\text { Correlation is significant at the } 0.01 \text { level (2-tailed)** } \\
\text { Correlation is significant at the } 0.05 \text { level (2-tailed)* }\end{array}$}} \\
\hline & & & & & & -taile & & & & & & \\
\hline
\end{tabular}

Table 7: Linear Regression between Air Pollutants and Diseases, 2014

\begin{tabular}{|c|c|c|c|c|c|}
\hline \multicolumn{2}{|c|}{ Variables } & \multirow{2}{*}{$\mathbf{R}$} & \multirow{2}{*}{$\mathbf{R}^{\mathbf{2}}$} & \multirow{2}{*}{$t$} & \multirow{2}{*}{ Significant (p) } \\
\hline Independent & Dependent & & & & \\
\hline SPM & Asthma & .821 & .675 & 2.881 & .045 \\
\hline RSPM & Asthma & .856 & .733 & 3.318 & .029 \\
\hline SPM & Bronchitis & .839 & .703 & 3.080 & .037 \\
\hline RSPM & Bronchitis & .896 & .803 & 4.041 & .016 \\
\hline RSPM & Eye Infection & $.829 a$ & .688 & 2.969 & .041 \\
\hline RSPM & Congested Heart & .859 & .737 & 3.351 & .029 \\
\hline
\end{tabular}

Source: ??

\section{SPM Vs Bronchitis}

The model summary contains the essential information revealing how well our regression model fit (or did not fit) the observed data. We see that $R$ is equal to .839 . Since this is a simple linear regression (i.e., we have only a single 
predictor), $\mathrm{R}$ is actually equal to the Pearson Product-Moment correlation coefficient between $\mathrm{X}$ and $\mathrm{Y}$. $\mathrm{R}$ Square in the model summary is computed as $R$ to the power of 2 . That is, it is equal to (.839)2. This is equal to 0.703. This expresses the proportion of variance in $Y$ that is "explained" or "accounted for" by knowledge of $X$. For our data, this means that approximately $70.3 \%$ of the variance in $Y$ can be accounted for by knowledge of $X$.

First, we interpret the constant. It is equal to 37.556. This means that the least-squares line touches the ordinate axis at a value of $Y=$ 37.556. Equally, it is also the predicted value for $\mathrm{Y}$ when $\mathrm{X}=0$. Hence,

$$
Y=-37.556+.113(\text { SPM) }
$$

For our data, this means that if SPM is equal to 0 (i.e., $X=0$ ), then the expected or predicted value for Bronchitis is -37.556 (i.e., $Y^{\prime}=$ 37.556). The values obtained for' $t$ ' is 3.080 , which is significant only at $5 \%$ level of significance.

\section{RSPM Vs Bronchitis}

Study results that correlation between RSPM and Bronchitis is highly correlated with each other (.896). R Square is computed as $R$ to the power of 2 that is 0.803 ; therefore, about 80.3 $\%$ of the variation in the Bronchitis is explained by RSPM. The regression equation appears to be very useful for making predictions since the value of $R^{2}$ is closer to 1 rather than 0 . In the column $B$, the constant represents the $y$ intercept and the RSPM represents our slope. The equation of the line found from the output is

$$
\mathrm{Y}(\text { Bronchitis })=-20.748+0.146(\text { RSPM })
$$

The tabulated values of ' $t$ ' (4.041) at 1\%, $2 \%$ and at $5 \%$ levels of significance for 4 degree of freedom ( $n-2$, where $n$ is 6$) 4.60,3.75$, and 2.78 respectively. It is obvious that our calculated value is significant only at $5 \%$ and $2 \%$ level of significance. So we can say that the variable $y$ (Bronchitis) is associated significantly with RSPM.

\section{RSPM Vs Eye Infection}

The summary of the linear regression reflects that there is a high positive correlation (.829) between RSPM and eye infection among the respondents. $R^{2}$ value is found to be moderate (.688), which reflects that about $68.8 \%$ of the variation in the eye infection is explained by RSPM. Constant represents the $y$-intercept and the RSPM represents our slope. The equation of the line found from the output is

$$
Y(\text { Eye Infection })=-31.294+0 . .426(\text { RSPM })
$$

Value of ' $t$ ' (2.969) is significant at the $5 \%$ level of significance.

\section{SPM Vs Congested Heart}

Study results that correlation between RSPM and congested heart problem is also highly correlated with each other (.859). R Square is computed as $\mathrm{R}$ to the power of 2 that is 0.737 ; therefore, about $73.7 \%$ of the variation in the occurrence of congested heart is explained by RSPM. The equation of the line found from the output is

$$
Y(\text { Bronchitis })=-20.748+0.146(\text { RSPM })
$$

The tabulated values of ' $t$ ' (4.041) is significant at the $5 \%$ levels of Significance for 4 degree of freedom ( $n-2$, where $n$ is 6$)$.

The regression analyses produce strong and consistent evidence that a link exists between ambient air pollution and health. There is associations (positive regression coefficients) do occur. The association between dependent variables (health problems) and independent variables (Air Pollutants) is strong and positive. 


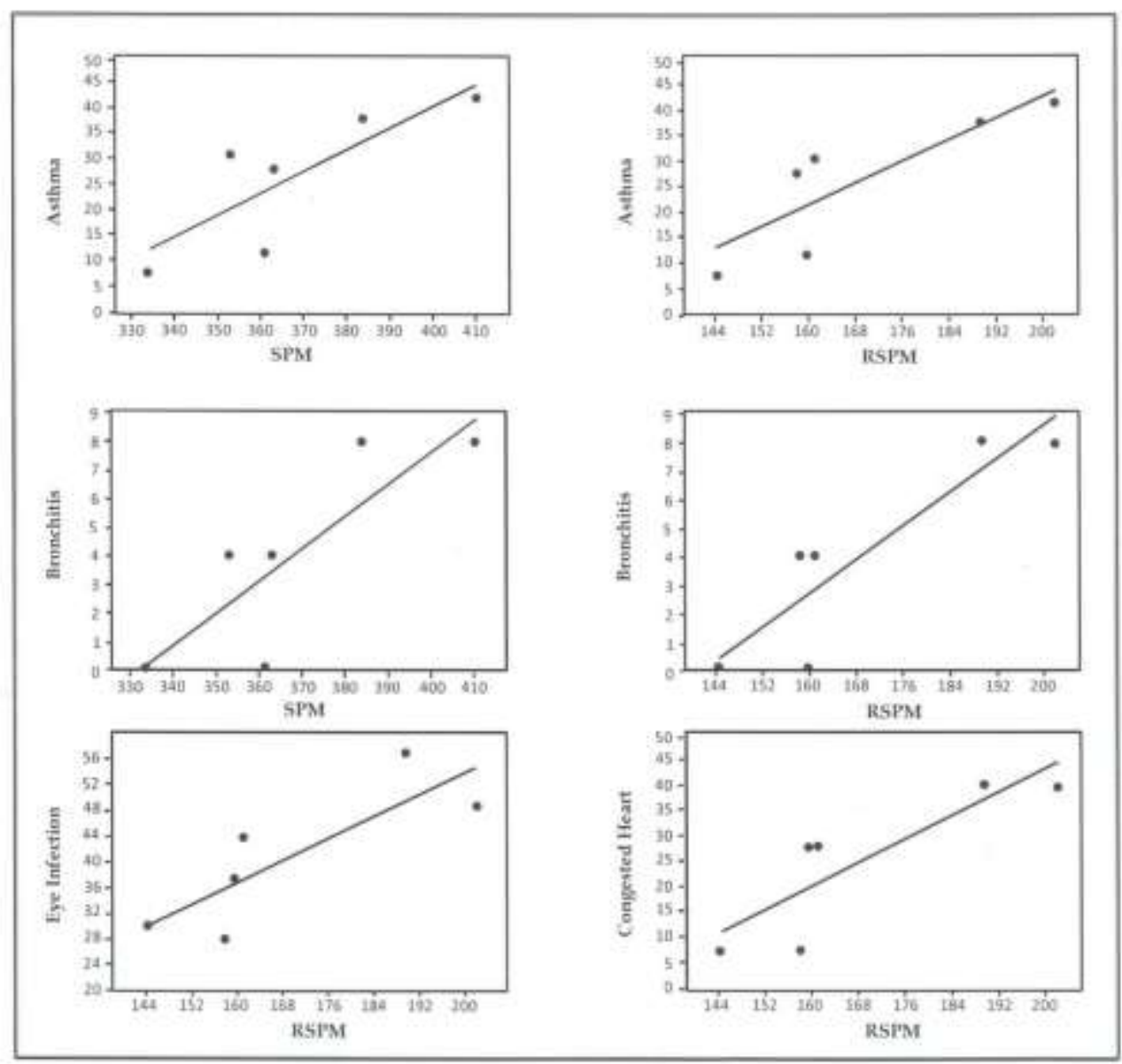

Figure 2

\section{Conclusion}

The paper presented a health oriented model for the purpose of determining problematic condition of the Lucknow city regarding air quality and its consequences on health. Using air quality data and correlating it with health problems, shows that poor health condition is associated with the low quality of air. The prevalence of airborne diseases varies according to age and occupation of the people engaged. From an environmental justice perspective, remedial action should be delivered through public health, environmental and social policy, and local planning processes.

\section{References}

Barman, S.C., Kumar, N., Singh, R., Kisku, G.C., Khan, A.H., Kidwai, M.M., Murthy, R.C., Negi, M.P.S., Pandey, P., Verma, A.K., Jain, G. and Bhargava, S.K. (2010). Assessment of Urban Air Pollution and it's Probable Health Impact, Journal of Environmental Biology (CTriveni Enterprises, Lucknow (India), 31(6), 913-920.

Becker, W.H., Schilling, F.J. and Verma, M.P. (1968). The Effect on Health of 1966. Eastern Subond and Pollution Episodes, Archives of Environmental Health, 16(3), 414-419.

Census of India (2011). Population Data, India.

Central Bureau of Health Intelligence (2012).

Directorate General of Health Services, Ministry 
of Health and Family Welfare, Government of India, 53-83.

\section{CPCB (2010). National Ambient Air Quality}

Standard, Central Pollution Control Board, New Delhi, available at, http://cpcb.nic.in/National_Ambient_Air Quality Standards. php (assessed on 15-03, 2014).

Dockery, D.W., Pope, C. A., Xu, X., Spengler, J.D., Ware, J.H., Fay, M.E., Ferris, B.G. and Speizer, F.E. (1993). An Association Between Air Pollution and Mortality in Six U.S. Cities. The New England Journal of Medicine, 329 (24), 1753-1759.

Ghose, M. K., Paul, R. and Banerjee, R. K. (2005). Assessment of the Status of Urban Air Pollution and its Impact on Human Health in the City of Kolkata, Environmental Monitoring and Assessment, Springer, 108, 151-167.

Government of India (2002). Tenth Five Year Plan 2002-2007, Draft Report. Planning Department, Government of National Capital Territory of Delhi, India.

Horaginamani, S.M. and Ravichandran, M. (2010). Ambient Air Quality in an Urban Area and its Effects on Plants and Human Beings: A Case Study of Tiruchirappalli, India, Kathmandu University Journal of Science, Engineering and Technology, 6 (II), 13-19.

IEA (2012). Report on $\mathrm{CO}_{2}$ Emissions from Fuel Combustion Highlights, (2012 Ed.), International Energy Agency, France.

IITR (2008). Report on Assessment of Ambient Air Quality of Lucknow City (Pre-monsoon, 2008), CSIR-Indian Institute of Toxicology Research (IITR), Lucknow.

IITR (2008). Report on Assessment of Ambient Air Quality of Lucknow City (Post-monsoon, 2008), CSIR-Indian Institute of Toxicology Research (IITR), Lucknow.

IITR (2009). Report on Assessment of Ambient Air Quality of Lucknow City (Post-monsoon, 2009), CSIR-Indian Institute of Toxicology Research (IITR), Lucknow.
IITR (2010). Report on Assessment of Ambient Air Quality of Lucknow City (Pre-monsoon, 2010), CSIR-Indian Institute of Toxicology Research (IITR), Lucknow.

IITR (2010). Report on Assessment of Ambient Air Quality of Lucknow City (Post-monsoon, 2010), CSIR-Indian Institute of Toxicology Research (IITR), Lucknow.

IITR (2010). Report on Assessment of Ambient Air Quality of Lucknow City (Pre-monsoon, 2010), CSIR-Indian Institute of Toxicology Research (IITR), Lucknow.

IITR (2011). Report on Assessment of Ambient Air Quality of Lucknow City (Pre-monsoon, 2011), CSIR-Indian Institute of Toxicology Research (IITR), Lucknow.

IITR (2011). Report on Assessment of Ambient Air Quality of Lucknow City (Post-monsoon, 2011), CSIR-Indian Institute of Toxicology Research (IITR), Lucknow.

IITR (2013). Report on Assessment of Ambient Air Quality of Lucknow City (Pre-Monsoon, 2013), CSIR-Indian Institute of Toxicology Research (IITR), Lucknow.

Ilyas, S.Z., Khattak, A.I., Nasir, S.M., Qurashi, T. and Durrani, R. (2010). Air Pollution Assessment in Urban Areas and its Impact on Human Health in the City of Quetta, Pakistan, Clean Techn Environ Policy, 12, 291-299.

Indo-Asian News Service (IANS) (2016).

Breathing poison: Air pollution kills over $5.5 \mathrm{mn}$ people worldwide annually, The Economic Times, available at http://articles.economictimes.indiatimes .com/2016-02-13/news/70593096_1_airpollution-indian-institute-poor-air-quality (accessed on 14-02-2016).

Jayamurugan, R., Kumaravel, B., Palanivelraja, S. and Chockalingam, M. P. (2013). Influence of Temperature, Relative Humidity and Seasonal Variability on Ambient Air Quality in a Coastal Urban Area, International Journal of Atmospheric Sciences, 2013, 1-7.

Kowalski, W.J. (1998). Airborne Respiratory Diseases and Mechanical Systems for Control of Microbes, HPAC Heating/Piping/Air 
Conditioning, July, 1998, Pennsylvania State University.

Kumar, A. (2007). Urbanization and

Environmental Concerns: the Indian

Perspective, New Dimensions in Urban

Geography, Tara Prakashan, Bodh Gaya, Bihar.

Los Angeles Times (2013). Air Pollution Causes Lung Cancer, World Health Organization, available at http://articles.latimes.com/ 2013/oct/17/science/ la-sci-sn-air-pollutioncauses-lung-cancer-20131017 (accessed on 11.01.2014.)

Meteorological centre (2010). Climatic Data, Amausi, Lucknow.

Ministry of Environment and Forests (2010), Annual Report 2010-2011, Government of India, New Delhi.

Narayan. P. (2009). Environmental Pollution, Principle, Analysis and Control. Satish Kumar Jain for CBS Publishers \& Distributors, New Delhi, 47-78.

Pandey, M. (1997). Will We Survive Environmental Hazards. Asia Pacific Research Information, Delhi.

Royal College of Physicians (2016). Every Breath we take the lifelong impact of air pollution: $A$ report of a working party, London, UK.

The Lancet Editorial (2016). Air pollution: Consequences and Actions for the UK, and Beyond, The Lancet, 387, 10021. 817, http://dx.doi.org/10.1016/S01406736(16)00551-1 (assessed on 27. 02. 2016).

Sampath, J. (2013). Chronic Respiratory IIIness Cases Rise with Air Pollution. The Times of India. Nov. 20, 2013. available at, http://articles. Times ofindia.indiatimes.com/2013-1120/chennai/44283978_1_air-pollution-thoracic - medicine-dust-allergy, (accessed on 11.01. 2014).

Shukla, A., Mishra, R. K. and Parida, M. (2010). Estimation of Composite Air Quality Index for
Lucknow, Institute of Town Planners, India Journal, 45-56.

The Times of India (2013a). $20 \%$ Lung Cancer Caused by Air Pollution. The Times of India, Nov 12, 2013. available at, http://timesofindia.indiatimes.com /india/20lung-cancer-caused-by-airpollution/articleshow/25614900.cms (accessed on 11.01.2014).

The Times of India (2013b). Air Pollution Fifth Leading Cause of Death in India: Study. The Times of India, Feb 14, 2013 available at, http://articles. timesofindia. indiatimes.com/2013-0214/pollution/37099315_1_air -pollutionpremature-deaths-toxics, (accessed on 11.01.2014).

Verma, A. and Singh, S. N. (2004). Air Quality Status of Central and Southern Regions of Lucknow City, India, Bulletin Environmental Contamination Toxicology, 73, 497-505.

WHO (2002). Health Impact Assessment of Air Pollution in the Eight Major Italian Cities. Regional Office for Europe, European Centre for Environment and Health, Rome Division, Italy, available on the Internet at www.euro.who.int/healthimpact.

WHO (2005). Air Quality Guidelines for Particulate Matter, Ozone, Nitrogen Dioxide and Sulfur Dioxide, Global update 2005, WHO Press, World Health Organization, Geneva, Switzerland, available at http://www.euro.who.int /Document/E87950.pdf., (accessed on 03-032013).

WHO (2014a). Ambient (outdoor) Air Pollution in Cities Database 2014, Geneva.

WHO (2014b). WHO's Ambient Air Pollution database - Update 2014, Public Health, Social and Environmental Determinants of Health Department, Geneva. 